\author{
Бардік Марина Афанасіївна \\ кандидат мистецтвознавства, \\ провідний науковий співробітник \\ науково-дослідного відділу історії та археології \\ Національного Києво-Печерського \\ історико-культурного заповідника \\ ORCID 0000-0003-3092-8929 \\ mb30@i.ua
}

\title{
ПРАВОСЛАВНИЙ ЖИВОПИС І НЕВІДОМИЙ МАЛЮНОК М. ВРУБЕЛЯ
}

\begin{abstract}
Мета статті - введення в науковий обіг і атрибуція невідомого малюнка М. Врубеля, виявлення зв'язку малюнка $з$ іншими творами художника. Методологія. У роботі використано комплекс методів: дедукції та порівняння, біографічний, компаративний, а також мистецтвознавчий аналіз, зокрема семантичний і стилістичний, емпіричне спостереження для атрибуції малюнка та включення його в контекст спадщини М. Врубеля. Наукова новизна. Введено в науковий обіг і атрибутовано малюнок М. Врубеля з колекції В. Є. Перевальського. Визначено вплив твору на тему панно із серії «Часи дня». Досліджено семантичний і стильовий зв'язок малюнка з монументальним живописом художника в Кирилівській церкві Києва. Доповнено спадщину М. Врубеля. Висновки. Атрибуція твору: «Врубель М. Пробудження. Портрет Надії Забели-Врубель, дружини художника. Харків. 1896 (вересень - грудень). Папір, графрітний олівець. 29 x 38,5 см. Із колекції В. Є. Перевальського. Київ». Тему пробудження М. Врубель використав для створення панно «Ранок» (1897). Обличчя дружини художник трактував як лик архангела Гавриїла (1884), написаного ним в Кирилівській церкві Києва. Образи дружини і архангела мають спільну семантико-стильову основу. Благовіщення, початок спасіння людства, асоціювався у М. Врубеля з новим етапом в житті і творчості, пов'язаним з дружиною Н. Забелою-Врубель.
\end{abstract}

Ключові слова: Михайло Врубель, Надія Забела-Врубель, Кирилівська церква в Києві.

Бардик Марина Афранасьевна, кандидат искусствоведения, ведущий научный сотрудник научноисследовательского отдела истории и археологии Национального Киево-Печерского историко-культурного заповедника

Православная живопись и неизвестный рисунок М. Врубеля

Цель статьи - введение в научный обиход и атрибуция неизвестного рисунка М. Врубеля, выявление связи рисунка з другими произведениями художника. Методология. В работе использован комплекс методов: дедукции и сравнения, биографический, компаративный, а также искусствоведческий анализ, в том числе семантический и стилистический, эмпирическое наблюдение для атрибуции рисунка и включения его в контекст наследия М. Врубеля. Научная новизна. Введен в научный обиход и атрибутирован рисунок М. Врубеля из коллекции В. Е. Перевальского. Определено влияние произведения на тему панно из серии «Времена дня». Исследована семантическая и стилистическая связь рисунка с монументальной живописью художника в Кирилловской церкви Киева. Дополнено наследие М. Врубеля. Выводы. Атрибуция произведения: «М. Врубель. Пробуждение. Портрет Надежды Забелы-Врубель, жены художника. Харьков. 1896 (сентябрь - декабрь). Бумага, графитный карандаш. 29 × 38,5 см. Из коллекции В. Е. Перевальского. Киев». Тему пробуждения М. Врубель использовал для создания панно «Утро» (1897). Лицо жены художник трактовал как лик архангела Гавриила (1884), написанного в Кирилловской церкви Киева. Образы жены и архангела имеют общую семантико-стилистическую основу. Благовещение, начало спасения человечества, ассоциировалось у М. Врубеля с новым этапом в жизни и творчестве, связанным с женой Н. Забелой-Врубель.

Ключевые слова: Михаил Врубель, Надежда Забела-Врубель, Кирилловская церковь в Киеве.

Bardik Maryna, PhD in Study of Art, leading researcher at the Scientific-Research Department of the History and Archaeology at the National Kyiv-Pechersk Historical and Cultural Preserve

The Orthodox Painting and Unknown Drawing by M. Vrubel

The purpose of the article is to introduce into scientific circulation and to attribute the unknown drawing by M. Vrubel also to explore a relationship to the one other artist's works. Methodology. The deduction and comparison, biographical and comparative methods, art study analysis, including semantic and stylistic ones, as well as empirical observation have been used in order to attribute the drawing and to include the one to the context of M. Vrubel heritage. Scientific novelty. The M. Vrubel's drawing from V. Perevalskyi's collection has been attributed and introduced into scientific circulation. The work influence the topic of the panel from the series Times of a Day has been determined. Semantic and stylistic connections of the drawing on the mural painting by the artist in St. Cyril's Church, Kyiv, have been observed. M. Vrubel heritage has been enriched. Conclusions. When creating the image of Nadiya Zabela, the creative process was diametrically opposed: the face of the archangel was manifested in the face of his wife. The semantics of their images are common in the Cyrillic composition and the Image. The Gospel is the beginning of the salvation of mankind, deliverance from the captivity of sin, "from the work of the enemy." Zabel's hope for the artist was the hope of recovering from the devastating illness of a former passion, a new stage in the life of a human creator. New love and a happy marriage for Mikhail Vrubel were an opportunity for salvation as their union strengthened the creative community. It's the drawing attribution. M. Vrubel. Awakening. Portrait of Nadiia Zabela-Vrubel, the Artist's Wife. Kharkiv. 1896 (September-December). Paper. Lead pencil. 29 x 38,5. V. Perevalskyi's collection. Kyiv. M. Vrubel used the awakening topic to create the panel Morning (1897). The artist interpreted his wife's face as the face of the Archangel Gabriel (1884) painted by him in St. Cyril's Church, Kyiv. Images of the wife and Archangel had a common semantic and stylistic basis.

(C) Бардік М. А., 2019 
M. Vrubel associated the Annunciation as the beginning of the salvation of mankind with a new period in his life and work, and with his wife N. Zabela-Vrubel.

Key words: Mykhailo Vrubel, Nadiia Zabela-Vrubel, Kyiv St. Cyril's Church.

Актуальність теми дослідження. Сказати нове слово про творчість Михайла Олександровича Врубеля - завдання надзвичайно складне та відповідальне. Художник, обдарований Богом такою мірою, що геній його не вписується в будь-який напрям мистецтва межі XIX-XX століть. Автор творів живопису монументального і станкового, іконопису, графріки станкової і книжкової, декоративного і театрально-декоративного мистецтва, скульптури. Людина трагічної долі, інтелігент у подвижницькому служінні справі життя - мистецтву і в благородному відношенні до людей.

Сміливість «взятися за перо» нам дозволяє обставина, яку без перебільшення можна вважати щастям для мистецтвознавця, - можливість ввести в науковий обіг невідомий до цього часу твір Михайла Врубеля.

Аналіз досліджень і публікацій. Ретельному вивченню, інколи «препаруванню», психологічного підґрунтя вчинків, біографічної лінії, творчої манери М. Врубеля присвячені численні публікації, які було розпочато ще публікаціями та спогадами О. Бенуа [1], К. Коровіна, Ф. Шаляпіна, С. Яремича - автора першої монографії про художника [2]. Для атрибуції невідомого твору М. Врубеля з приватної колекції стали у нагоді видання, що містять листи, написані самим художником й адресовані йому; історико-біографічні та мистецтвознавчі праці, у яких наведено спогади сучасників і фракти тогочасного художнього життя, аналіз творчості й окремих пам'яток [3; 4; 5; 6; 7], альбоми і каталоги творів митця 3 колекцій Національного музею «Київська картинна галерея» (далі - НМККГ), Державної Третьяковської галереї (далі - ДТГ), Державного Російського музею (далі - ДРМ), приватних збірок [8; 9; 10].

Мета статті - введення в науковий обіг і атрибуція невідомого малюнка М. Врубеля, виявлення зв'язку малюнка з іншими творами художника.

Виклад основного матеріалу. Малюнок, який ми досліджуємо (далі - Малюнок), зберіг Василь Євдокимович Перевальський - дійсний член (академік) Національної академії мистецтв України, народний художник України, професор, завідувач кафедри графічних мистецтв Національної академії мистецтва і архітектури. Малюнок є зображенням молодої жінки, виконане графрітним олівцем на папері, пожовклому від часу і трохи зім'ятому, оскільки в минулому його, вочевидь, складали вчетверо. У правому нижньому куті графітним олівцем зроблено підпис: М Врубель (рис. 1).

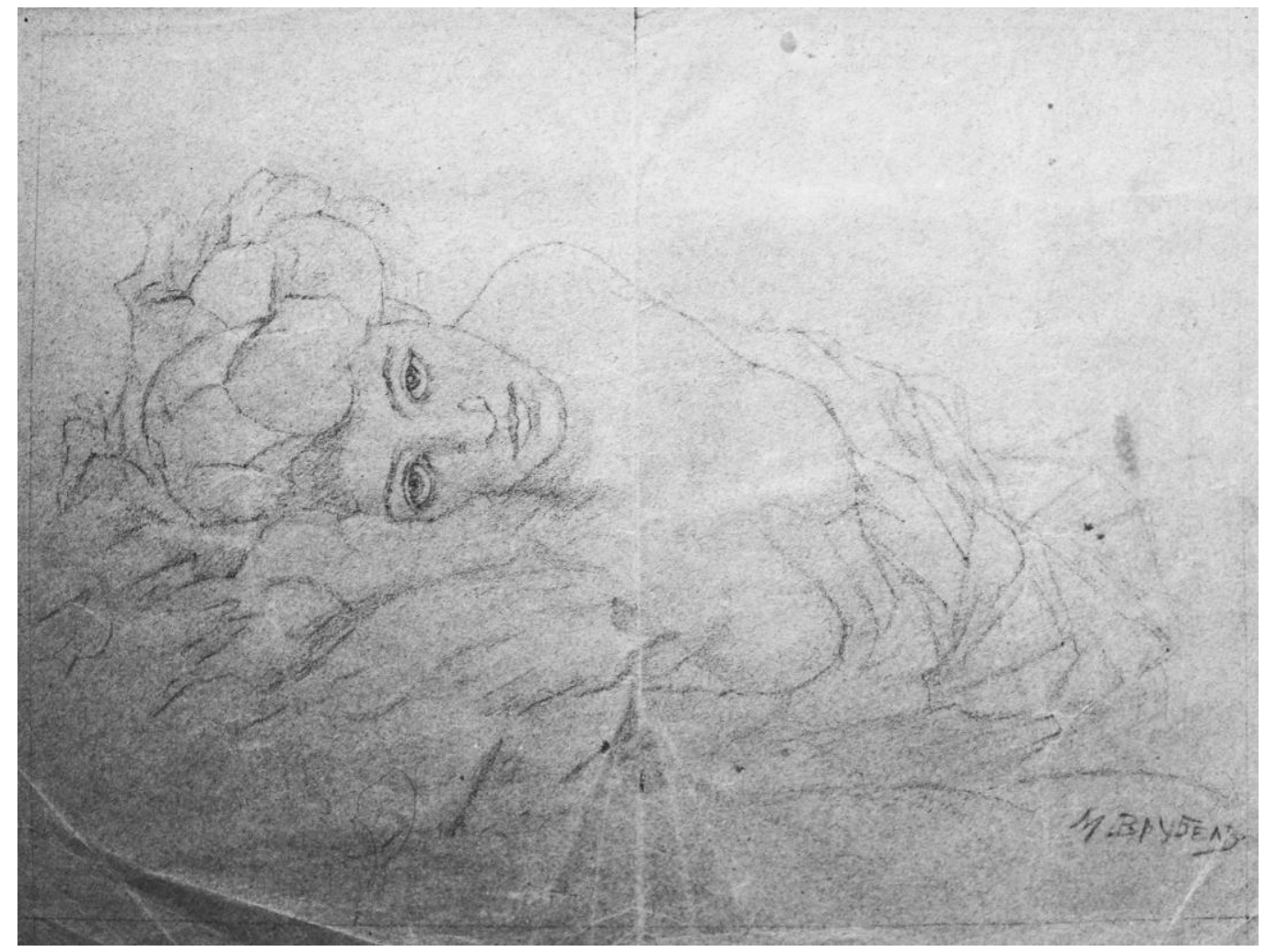

Рис. 1. М. Врубель. Пробудження. Портрет Надії Забели-Врубель, дружини художника. Харків. 1896. Папір, графітний олівець. 29 × 38,5. Колекція В. Є. Перевальського Публікується вперше 


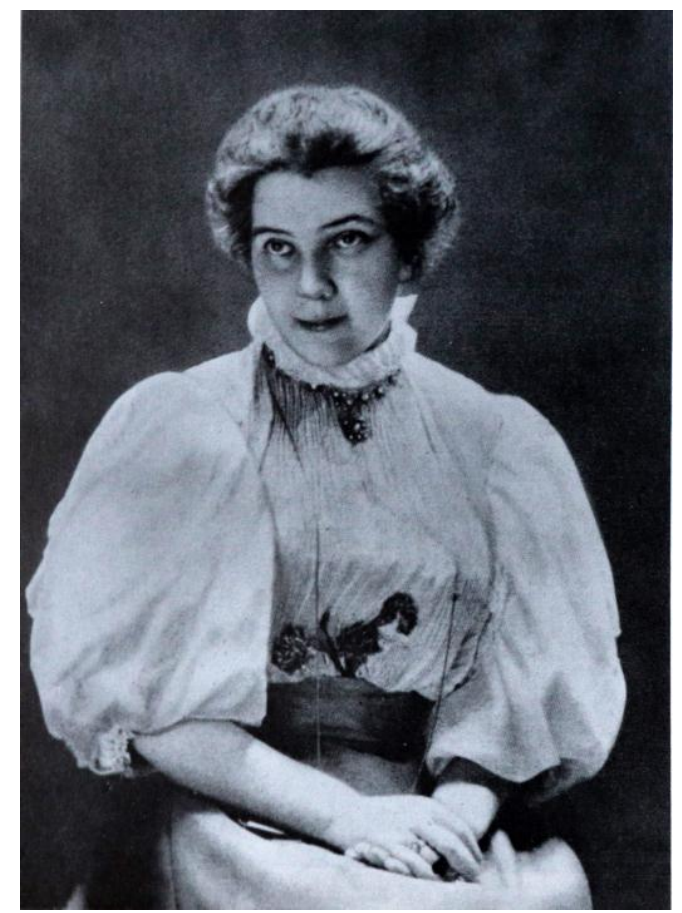

Рис. 2. Надія Іванівна Забела-Врубель. Фотографія. 1890-ті (Із видання: «Михаил Врубель. Альбом / М. Ю Герман...1989. С. 216»)

Далеко не всі, навіть добре відомі, твори М. Врубеля підписані ним, адже художник «не тремтів» над ними і міг просто дарувати або зовсім дешево віддати [1, 181], хоча грошей інколи не вистачало на їжу. Тим цінніше, що на Малюнку підпис $е$ причому такий шрифт для написання свого прізвища М. Врубель використовував неодноразово. Його зустрічаємо у ранніх творах: в акварелі «Заручини Марії з Іосифом» (1881, ДРМ) [9, рис. 2], на малюнку «Архангел Михаїл» (1884, НМККГ) [10, 119]. Утім такий підпис більш притаманний творам зрілого періоду, починаючи з 1890-х років: в ілюстраціях 1890-1891 років до творів М. Лермонтова «Дуель Печоріна з Грушницьким», «Казбіч і Азамат» (ДТГ) [9, рис. 47, 49], у невимовно чарівній за композиційно-колірним втіленням теми чудесного перетворення картині «Царівна-Лебідь» (1900, ДТГ) [9, рис. 105], у сповненому трагізму портреті сина художника Сави, померлого зовсім маленьким (1902, ДРМ) [9, рис. 141]. Цей підпис художник використовував також у поєднанні з першою літерою свого імені, коли «М» та «В» поєднувалися: серед ілюстрацій до творів М. Лермонтова - в акварелі «Вершник, що скаче» (1890-1891, ДТГ) [9, рис. 50], у портреті Надії Забели-Врубель (1904, ДРМ) [9, 244], в етюді «Іоанн Хреститель» (1905, ДРМ) [8, рис. 51; 9, рис. 133]. У підписі художника на Малюнку літера «М» відокремлена від прізвища. Подібним чином М. Врубель підписав малюнок «Шестикрилий серафим» (1905, Всеросійський музей О. С. Пушкіна) [9, рис. 134] і портрет О. А. Станкевич (1906, ДТГ) [8, рис. 55]. Отже, на Малюнку підпис М. Врубеля є автентичним, що засвідчує його авторство.

Наявність авторського підпису вказує, що для М. Врубеля Малюнок був завершеним за своїм задумом твором, хоча, на перший погляд, той здається начерком: лінія, спокійна і впевнена, окреслює контури обличчя жінки, її відкритих плечей, грудей, бганки простирадла. Вдало обіграно формат паперу, близький до золотого перетину, для розкриття теми пробудження від солодкого сну, коли душа і світ навколо сповнені тишею і спокоєм. Мотив ліричний, а образ молодої жінки піднесений, значимий, строгий. Обличчя, трохи звужене внизу, із зведеними до верху виразними очима, гіпнотично притягує погляд. Площинне трактування тіла, типове Врубелівське (згадаймо малюнок «Ліжко» (1904-1905, ДРМ) [9, рис. 142] із циклу «Безсоння») трактування простирадла сукупністю кристалів, лінії яких звужуються у правій частині для ефекту глибини, - ця продумана геометрія будується як система навколо обличчя моделі - сугестивного центру композиції. Остання, звичайно, є не побутовою сценою, а портретом. У ньому відкрита авторська техніка рисунка. Вона формувалася під час занять в Академії Мистецтв у П. Чистякова, який навчав бачити і виділяти в об'ємних формах плани, площини. У вигляді гострокутних площин М. Врубель міг представити предмети, одяг, квіти, пейзажне тло. Утім більш плавними абрисами передано бганки тканини, яка прикриває волосся жінки. Цей прийом художник відпрацьовував у штудіях, наприклад, в етюді «Оголений натурник» (1882-1883, НМККГ) [10, 83]. У Малюнку звичайний прийом закриття волосся тканиною маестро використав як інструмент в оркестровці твору для гармонізації із загальним ритмом ліній, для створення художнього враження, водночас прекрасного і загадкового. 
Великі очі, прямий ніс, звужене до низу обличчя, а над верхньою губою праворуч ледь намічена родимка - ці особливості лиця і почуття любові, яким дихає Малюнок М. Врубеля, є підказкою, щоб, занурившись у біографічні описи, відповісти на питання, кого замалював художник. Жінку на Малюнку впізнаємо на фотографії Надії Іванівни Забели, датованій 1890-ми роками [9, 216 ] (рис. 2). У 1895-му вона познайомилася з Михайлом Олександровичем, у липні 1896-го вони одружились. Надія ЗабелаВрубель була чарівною жінкою і талановитою оперною співачкою, переливи ії̈ голосу створювали хвилюючу музичну феєрію. М. Врубель, людина тонкої емоційної організації, міг безкінечно слухати опери за її участі, розробляв для неї сценічні костюми, увічнював у численних творах. Одним із них є відомий портрет Надії Іванівни, написаний 1898 року, у літньому вбранні в стилі «Еmріге», зшитому за задумом М. Врубеля [9, рис. 102]. Ґенеза її вигадливого капелюха бачиться у бганках тканини, що обгортає волосся Надії Іванівни на Малюнку. Живопис, музика, театр були життєвим середовищем М. Врубеля та його дружини.

Визначити час і місце створення Малюнка суттєво допомагає свідчення В. Перевальського про те, що свого часу Малюнок було знайдено в Харкові. Дійсно, після вінчання 28 липня 1896 року в Женеві, Михайло Олександрович і Надія Іванівна провели медовий місяць у Люцерні, а у вересні 1896 року приїхали до Харкова, де у Надії Іванівни мали відбутися гастролі в місцевому театрі [9, 217]. Тоді М. Врубеля сприймали ще як чоловіка примадонни. У біографічному літописі, наведеному С. Яремичем, зазначено, що влітку 1896 року відбулося весілля М. Врубеля, потім вони з дружиною перебували в Швейцарії, в Італії, а восени приїхали до Харкова. У січні - березні вони вже були в Москві $[1,176]$. За спогадами співачки М. Дулової, вона зустрілась із подружжям Врубелів у Харкові на початку театрального сезону 1896 року, потім вони залишили Харків, і взимку 1897 року вона знову зустріла Надію Іванівну та Михайла Олександровича в Санкт-Петербурзі під час гастролей московської опери С. Мамонтова [3, 258-260]. Отже, харківський період в творчості М. Врубеля, такий короткий і такий щасливий у його житті, - вересень - грудень 1896 року. Цим часом датуємо Малюнок.

Розкрита у ньому тема пробудження надихнула художника створити наступного року монументально-декоративне панно «Ранок» (1897, ДРМ) із серії «Часи дня» для будинку С. Морозова [9, рис. 76].

Трактування обличчя дружини художника на Малюнку потребує окремої уваги. Надію Забелу М. Врубель писав у різних художніх образах, придуманих ним самим і сценічних, за різних життєвих обставин. Варто згадати такі його твори, як «Гензель і Гретель» (1896, ДРМ), «Муза» (1896, приватна колекція, Москва), «Primavera» (1897, ДРМ), «Царівна Волхова» (1898, ДРМ), портрети у вбранні в стилі «Empire» (1898, ДТГ) і на тлі берізок (1904, ДРМ) [8; 9], - в усіх варіаціях костюму й антуражу зображення Надії Іванівни зберігає індивідуальні риси: овальне і помітно видовжене обличчя, вузьке і загострене підборіддя, трішки випнута нижня губа, великі й широко розкриті очі. 3 цього приводу цікавим є зауваження сестри Надії Іванівни, Катерини Іванівни Ге, яка згадувала: «Врубель дуже захоплювався зовнішністю і статурою сестри... У зовнішності сестри не було нічого класичного і правильного, і я чула відгук, що Врубель видумав красу сестри і здійснив її в портретах, хоча, як на мене, він часто перебільшував саме її недоліки, оскільки вони особливо подобалися йому» [3, 209]. Яскравим прикладом акцентування особливостей обличчя Н. Забели є її незакінчений портрет 1905 року (ДРМ) [9, рис. 139], у якому представлено жінку, що вже поховала дитину і переживала тяжку хворобу коханого чоловіка (художник гіпертрофовано намалював родимку та скривлену нижню губу). М. Врубель виділяв певні риси для створення художнього образу.

На Малюнку обличчя Надії Іванівни, серйозне й одухотворене, дещо скориговане - із класично правильними пропорціями і рисами. Його первообраз знаходимо в прекрасному лику архангела Гавриїла, написаного М. Врубелем 1884 року в Кирилівській церкві Києва (на північному стовпі тріумфальної арки). В архангела згідно з візантійським каноном лик трохи звужений унизу, погляд великих очей спрямований угору, ніс і губи ідеальні у чітко окреслених формах. Малюючи в стилі кирилівських фресок, у стилі своєї ж композиції, включеної в образотворче середовище середньовічного православного стінопису, художник надав моделі на Малюнку піднесеного вигляду. Хіба що ледь помітна родимка над губою жінки нагадує про земну реальність.

Час створення Малюнка був райським, сповненим щастям взаємного кохання двох творчо обдарованих людей (цей рай розіб'ється після хвороби й смерті дитини, невиліковної хвороби і сліпоти художника М. Врубеля, втрати голосу оперної співачки Н. Забели, не кажучи вже про безліч повсякденних негараздів). Творчим підйомом були позначені роботи М. Врубеля 1884 року, коли він доповнював своїми композиціями мозаїки Софійського собору XI століття і фрески ХІІ століття Кирилівської церкви [6, 72-115; 10, 22-77]. Духовна вертикаль давньоруського монументального мистецтва була співзвучною тональності душі М. Врубеля, яка прагнула до трансцендентного.

Трактування обличчя Надії Забели в аналогії лику архангела Гавриїла суголосно тенденції символізму в тогочасному європейському мистецтві. Натурну замальовку М. Врубель довів до рівня графічної метафори. С. Яремич у своїй монографії навів підготовчий ескіз художника до «Благовіщення», виконаний того ж, 1884 року [2, 22]. У ньому погляд архангела спрямований прямо на Марію, і сцена прочитується як конкретний у часі земний епізод. У храмовому образі архангела Гавриїла, а 
потім і в образі дружини на Малюнку, погляд очей уверх створює надземну реальність, коли час поступається вічності і земна подія набуває доленосного смислу.

Варто згадати, що в іконостасі Кирилівської церкви знаходиться ікона Богородиці з Немовлям (1885), в образі якої М. Врубель написав Емілію Прахову, дружину історика мистецтва А. Прахова, роботодавця художника. Справедливими і переконливими є судження дослідників творчості М. Врубеля [4; 5] про рокову роль сім'ї Прахових у душевних митарствах художника, відмові на участь в розписуванні Володимирського собору (тепер кожен цінитель живопису відзначає його оригінальні орнаменти в храмі), у створенні іміджу М. Врубеля як талановитої, але ненадійної, неврівноваженої людини. Нав'язливий образ Е. Прахової - хвороба, що змусила художника надати Богородиці риси жінки, вельми далекої від святості.

Під час створення образу Надії Забели творчий процес відбувався діаметрально протилежно: лик архангела був явлений в обличчі дружини. Семантика їхніх образів спільна в кирилівській композиції та Малюнку. Благовіщення - початок спасіння людства, визволення від полону гріха, «від роботи ворожої». Надія Забела для художника стала надією на одужання від руйнівної хвороби колишньої пристрасті, на новий етап у житті людини-творця. Нове кохання і щасливий шлюб для Михайла Врубеля були можливістю спасіння, адже їхній союз скріплювала творча співдружність. I хто знає, якби живим і здоровим був їхній син Савочка, а вони теж при доброму здоров"ї розвивали свої таланти (виконуючи Божественне призначення людини - любити й створювати красу в усіх її проявах), наше мистецтво - образотворче, декоративне, театральне - збагатилося б безцінними творами.

Наукова новизна. Введено в науковий обіг і атрибутовано малюнок М. Врубеля з колекції В. Є. Перевальського. Визначено вплив твору на тему панно із серії «Часи дня». Досліджено семантичний і стильовий зв'язок малюнка з монументальним живописом художника в Кирилівській церкві Києва. Доповнено спадщину М. Врубеля.

Висновки. Атрибуція твору: «М. Врубель. Пробудження. Портрет Надії Забели-Врубель, дружини художника. Харків. 1896 (вересень - грудень). Папір, графітний олівець. 29 х 38,5 см. Із колекції В. Є. Перевальського. Київ». Тему пробудження М. Врубель використав для створення панно «Ранок» (1897). Обличчя дружини художник трактував як лик архангела Гавриїла (1884), написаного ним в Кирилівській церкві Києва. Образи дружини і архангела мають спільну семантико-стильову основу. Благовіщення, початок спасіння людства, асоціювався у М. Врубеля з новим етапом в житті і творчості, пов'язаним з дружиною Н. Забелою-Врубель.

\section{תimepamypa}

1. Бенуа А. Врубель. Мир искусства. 1903. № 10-11. С. 175-182.

2. Яремич С. Михаил Александрович Врубель: жизнь и творчество. Москва : И. Кнебель, 1911. 187 с.

3. Врубель. Переписка. Воспоминания о художнике / Э. И. Гомберг-Вержбинская, Ю. Н. Подкопаева. Ленинград, Москва : Искусство, 1963, 362 с.

4. Тарабукин Н. М. Михаил Александрович Врубель. Москва : Искусство, 1974. 174 с.

5. Суздалев П. К. Врубель. Москва : Советский художник, 1991. 368 с.

6. Марголіна І. Ангели Врубеля. Київ : Либідь, 2012. 144 с.

7. Домитеева В. М. Врубель. Москва : Молодая гвардия, 2014. 477 с.

8. Врубель / С. Г. Капланова. Ленинград : Аврора, 1975. 215 с.

9. Михаил Врубель. Альбом / М. Ю. Герман. Ленинград : Аврора, 1989. 263 с.

10. Врубель і Київ / О. Друг, І. Марголіна, К. Ладиженська. Київ : Фенікс, 2013. 421 с.

\section{References}

1. Benua, A. (1903). Vrubel. Mir iskusstva. 10-11. 175-182 [in Russian].

2. Yaremich, S. (1911). Mikhail Aleksandrovich Vrubel's Life and Artwork. Moscow: I. Knebel [in Russian].

3. Gomberg-Verzhbinskaya, E. I., \& Podkopaeva, Yu. N. (1963). Vrubel. The Correspondence and Memoirs of the Artist. Leningrad, Moscow: Iskusstvo [in Russian].

4. Tarabukin, N. M. (1974). Mikhail Aleksandrovich Vrubel. Moscow: Iskusstvo [in Russian].

5. Suzdalev, P. K. (1991). Vrubel. Moscow: Sovetskiy khudozhnik [in Russian].

6. Marholina, I. (2012). Vrubel's Angels. Kyiv: Lybid [in Ukrainian].

7. Domiteeva, V. M. (2014). Vrubel. Moscow: Molodaya gvardiya [in Russian].

8. Kaplanova, S.G. (1975). Vrubel. Leningrad: Avrora [in Russian, in English, in French, in German].

9. German, M. Yu. (1989). Mikhail Vrubel. Album. Leningrad: Avrora [in Russian]. in English].

10. Drug, O., \& Marholina, I., \& Ladyzhenska, K. (2013). Vrubel and Kyiv. Kyiv: Feniks [in Ukrainian, in Russian, 